Arch. histol. jap. Vol. 31, No. 3/4 (1970)

p. $433-454$

Department of Anatomy (Prof. T. ITo), Gunma University School of Medicine, Maebashi, Japan

\title{
Light and Electron Microscope Observations on the Islets of Langerhans in Carassius carassius longsdorfii*
}

\author{
Kan Kobayashi and Yoshiyuki Takahashi \\ （小林宽と高橋嘉幸）
}

Light microscopic studies on the islets of fishes have been carried out by many authors. Concerning the islets of cartilaginous fishes, Thомas (1940) could identify three cell types, A, B and D in all seven elasmobranchial species examined, and KERN (1964) found them in Raja fullonica, Torpedo marmorata and ocellata. ÖstBERG, Hellerström and Kern (1966) revealed in Raja, Torpedo and Scyliorchinus $\mathrm{A}_{1}$ (argyrophil A cell), $A_{2}$ (nonargyrophil A cell) and B cells without mentioning D cells. FujitA (1962), who examined holocephalian fish, Chimaera monstrosa, demonstrated, besides $\mathrm{A}, \mathrm{B}$ and D cells, numerous cells of unknown type which he designated as X cells.

As for the islets of teleostean fishes, Watanabe (1960) described in the carp three types of islet cells, A, B and D, while FALKMER (1961) reported in Cottus scorpius, and Planas and Garcia (1964) in tunny fish two types of cells, A and B. Further, Sivadas (1964) described B cells as the only islet cell type in Tilapia mossambica.

There are several electron microscopic studies on the islets of Langerhans in teleosts. Watanabe (1960) and Titlbach (1966) could electron microscopically classify three types of islet cells, A, B and D in the carp (Cyprinus carpio), although they differed in opinion concerning the criteria for identifying A and B cells. Recently, FaLLer and LANGE (1969) electron microscopically observed five islet cell types, B, II, III, IV and V in the same material.

In the present study, the pancreatic islets of Carassius carassius longsdorfii, which like Cyprinus carpio belongs to the teleostean group Cyprinidae, have been observed by light and electron microscopy since the islets of this species have hitherto been investigated neither light nor electron microscopically.

\section{Material and Methods}

Adult Carassius carassius longsdorfii Temminck and Schlegel with an average head-tail length of about $20 \mathrm{~cm}$ and weighing approximately $50 \mathrm{~g}$ were used in this study. For the light microscopy, tissue blocks of the pancreas were fixed in Levi's and Bouin's fluid. The paraffin-embedded specimens were cut in $4 \mu$ thick serial sections and stained in paraldehydefuchsin-light green-orange G (AFLO) and azan. For the demonstration of the argyrophil cell the silver impregnation method of HeLLMAN and Hellerström (1960) was employed.

For electron microscopy, the macroscopically visible large islets (BRockMANN bodies) were carefully isolated and fixed for two hours in a cold, veronal-buffered 1\% osmic acid solution containing $3 \%$ sucrose. The materials were embedded in Epon 812 (LuFT, 1961) and cut with glass knives on a Porter-Blum ultratome. The ultrathin sections were mounted on copper grids and were contrasted with uranyl acetate and

* This paper is dedicated to Prof. Toshio Ito in the memory of his retirement. 
lead acetate to be observed and micrographed with JEM-5, JEM-7 and JEM-7A electron microscopes.

\section{Observations}

\section{Light Microscopic Observations}

The pancreatic islet tissue of Carassius forms numerous well-defined round bodies of varying sizes scattered throughout the exocrine pancreas. Macroscopically visible islets, the so-called principal islets of Brockmann's bodies, are also found in the mesentery. These islets are exclusively composed of endocrine islet cells and surrounded by a relatively thick connective tissue sheath (Fig. 1). In the azan or AFLO stained preparations at least three islet cell types, A, B and D cells, are distinguished in the islets. The $\mathrm{B}$ cells usually make within the islets thick cell cords or groups which run tortuously, anastomosing with each other to form a network distributed throughout the islets (Fig. 1). Within these B-cell cords or groups a small number of A and D cells are intermingled. The majority of these cells are distributed in the meshes of the B cell network (Fig. 1,2); $\Lambda$ cells often make small groups of a few cells, but D cells scatter mostly solitarily. In the preparations treated by the silver impregnation method of Hellman and Hellerström (1960) argyrophil islet cells are demonstrated.

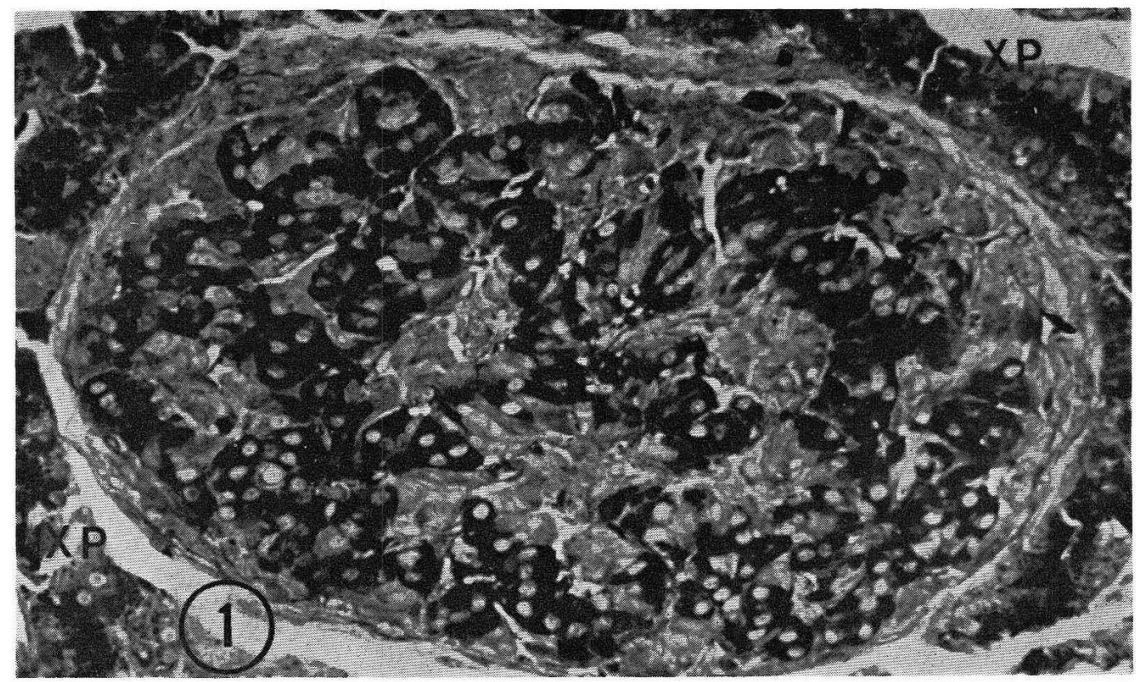

Fig. 1 Low power view of an islet of the Carassius embedded in the exocrine pancreas $(X P)$. The B-cell cords (dark) are distributed throughout the islet and in the meshes of their network, A, D and clear islet cells are packed. Levi, aldehydefuchsin-light green orange G (AFLO). $\times 320$

As observed in Figure 3, these cells are generally scattered singly among other nonargyrophilic islet cells. They are round, polygonal or elongated in shape, and occasionally show slender cytoplasmic processes protruding between non-argyrophilic elements. It is noticed that they coincide with $\mathrm{D}$ cells in shape, distribution and number

Fig. 3, Argyrophil islet cells (dark) in the islet of the Carassius. They are mostly singly scattered within the islet, Bouin, Silver-impregnation method of Hellman and Hellerström. $\quad \times 1,440$ 


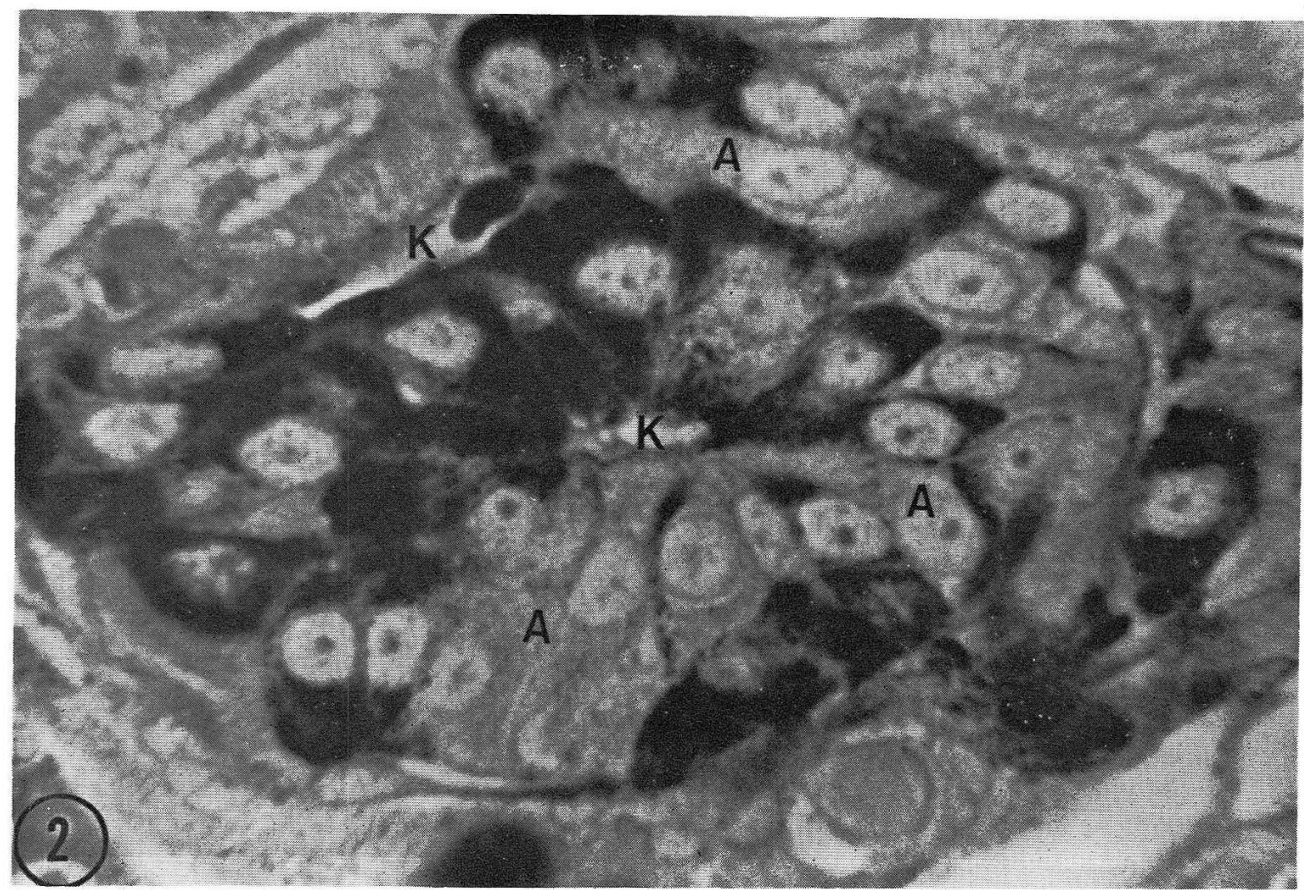

Fig. 2. High power view of a portion of the B-cell cord (dark) containing some A cells $(A)$. Most islet cells show a clear polarity towards the capillaries $(K) \quad$ Levi, AFLO. $\times 1,440$

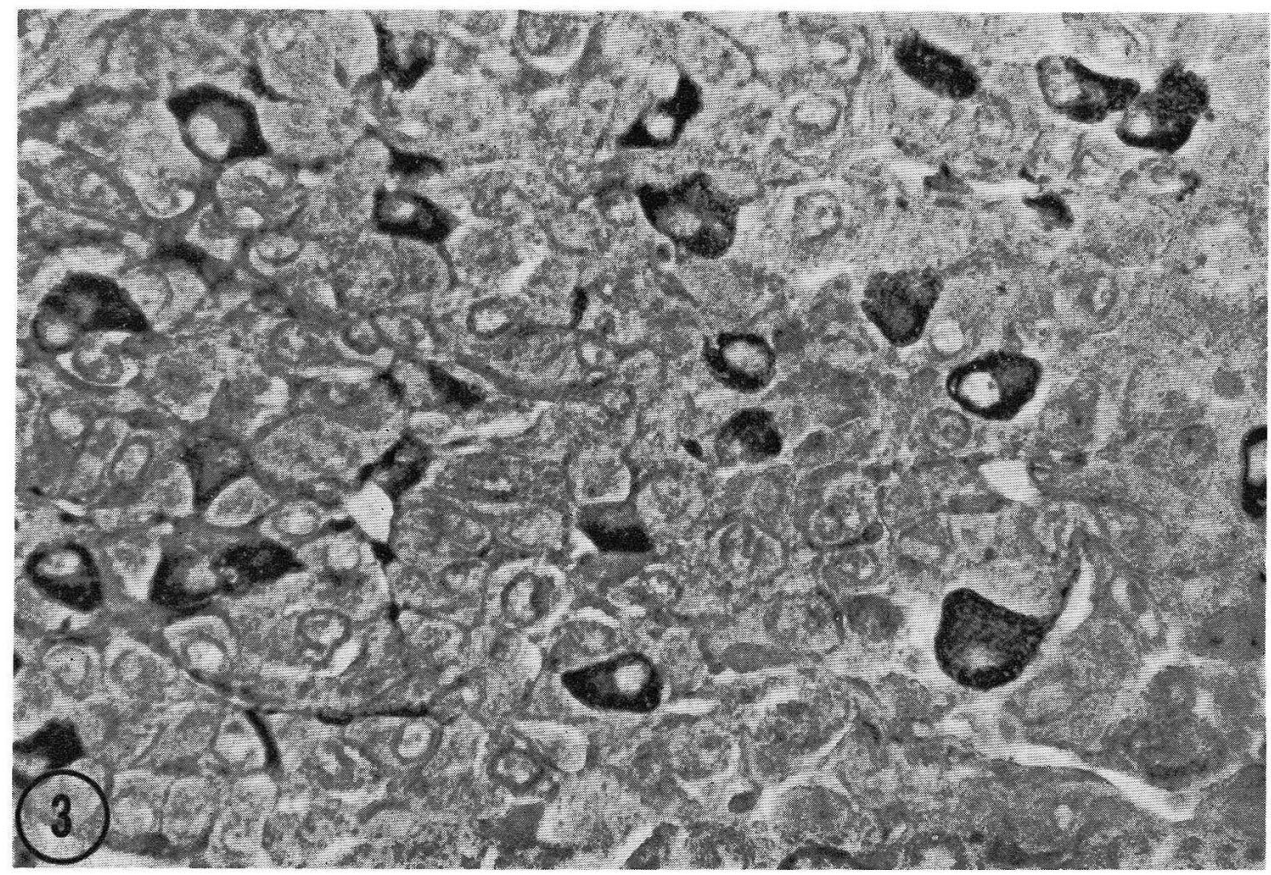


suggesting the identity of the argyrophil islet cells with D cells. All islet cell types show a polarity towards the blood capillaries that richly penetrate the islet tissue (Fig. 2).

Besides these A, B and D cells there sometimes appear "clear" or "agranular" cells that are not strongly stained by any dye used. As described later, they have also been identificd by electron microscopic observations.

The population ratio of $\mathrm{A}, \mathrm{B}, \mathrm{D}$ and agranular cells in the Carassius islets is apporoximately 25: 50:15: 10 .

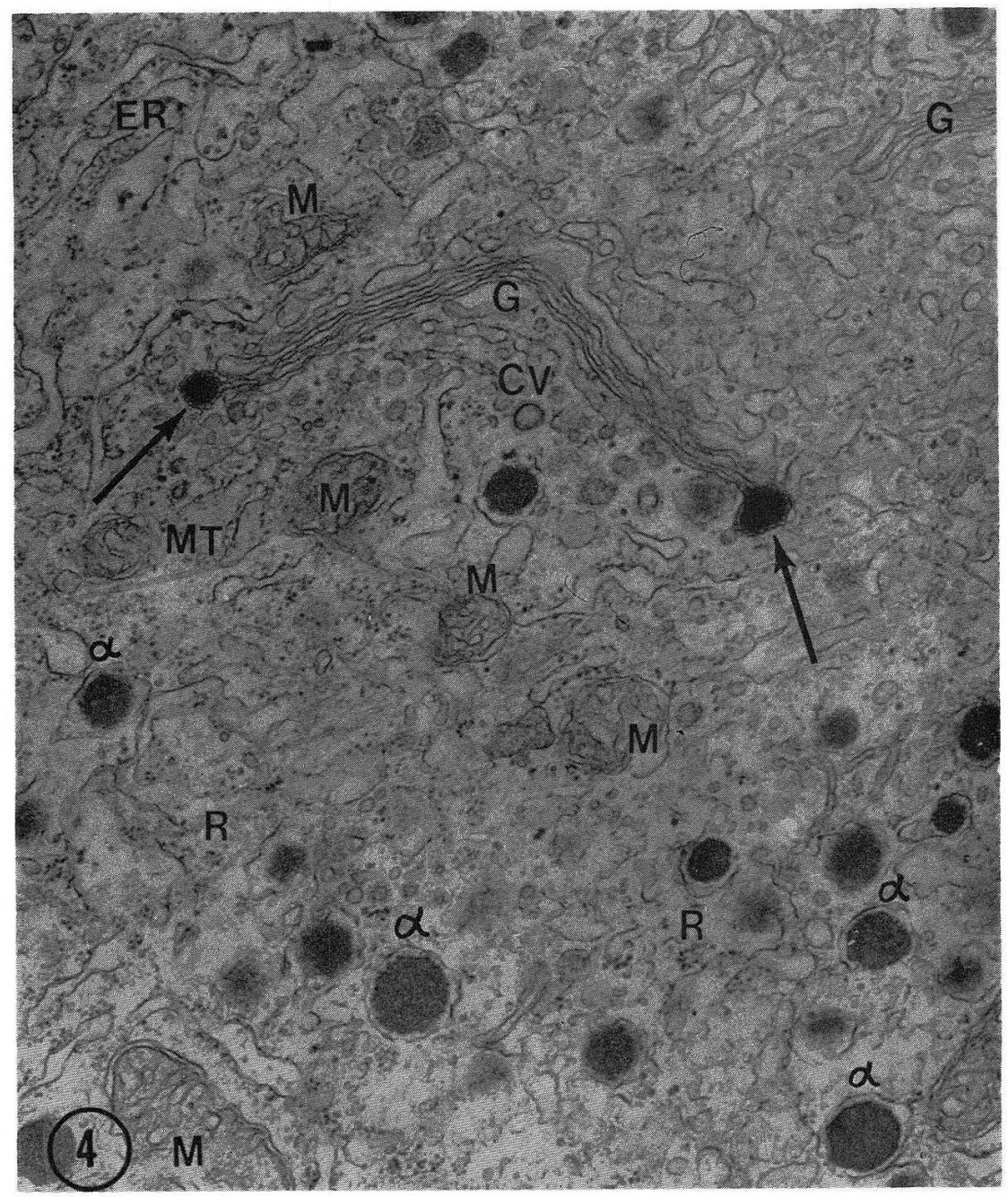

Fig. 4. Electron micrograph of the cytoplasmic portion of an $\Lambda$ ccll. $\Lambda$ Golgi complex $(G)$, mitochondria $(M)$, cisternae of the granular endoplasmic reticulum $(E R)$, smooth vesicles, free ribosomes aggregated into cluster $(R)$, occasional microtubules $(M T)$ and $\alpha$-granules $(\alpha)$ are seen. The bulbously dilated ends of the elongated cisternae of the Golgi lamellae contain a minute dense granule $(\uparrow)$ which is presumed to be pinched off into an immature $\alpha$-granule. $C V$ coated vesicle $\times 28,300$ 


\section{Electron Microscopic Observations}

\section{A cells}

Oval or rod-shaped mitochondria which have irregular cristae and occasionally a few intramitochondrial granules are scattered in the cytoplasm. The elements of rough surfaced endoplasmic reticulum are richly found, often occupying large parts of the cytoplasm and exhibiting in random places lamellar patterns of flattened sacs oriented in parallel. Ribosomes are irregularly studded on the outer surface of the cisternae of the granular endoplasmic reticulum. Free ribosomes are also distributed

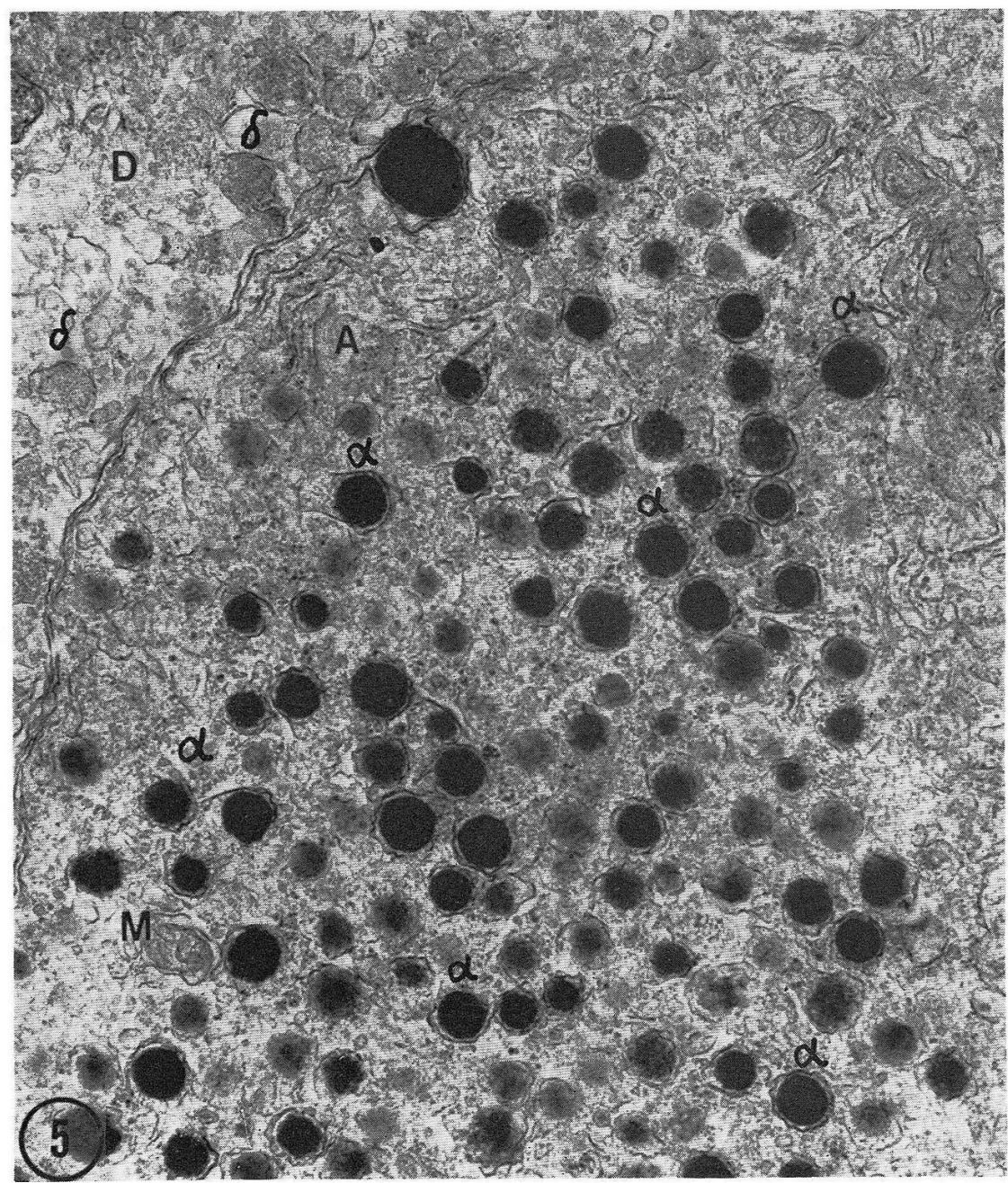

Fig. 5. The $\alpha$-granules $(\alpha)$ of an A cell $(A)$ of the Carassius. They consist of a round membranous sac and a spherical core of high electron density; the clear space between the two is conspicuous. A large $\alpha$-granule is found in the intercellular space between the A and D cell $(D)$ in a deep concavity on the surface of the A cell, suggesting emiocytotic release of $\alpha$-granules. $M$ mitochondria, $\delta \delta$-granules. $\quad \times 22,500$ 
in a considerable amount in the cytoplasm, tending to aggregate in small clusters. Sparse glycogen particles occur among them. The Golgi apparatus consists of elongated lamellae, numerous vesicles and a few vacuoles; some of the vesicles are of a coated type (Fig. 4). Small, probably immature secretory granules are often found near the Golgi complex (Fig. 4), and within the bulbous dilations of the Golgi lamellae dense spherical bodies are frequently included which likely are transformed by pinching-off into the former type of granules. Membranous elements of the smooth surfaced endoplasmic reticulum are also scattered in the cytoplasm mingling with the rough surfaced elements.

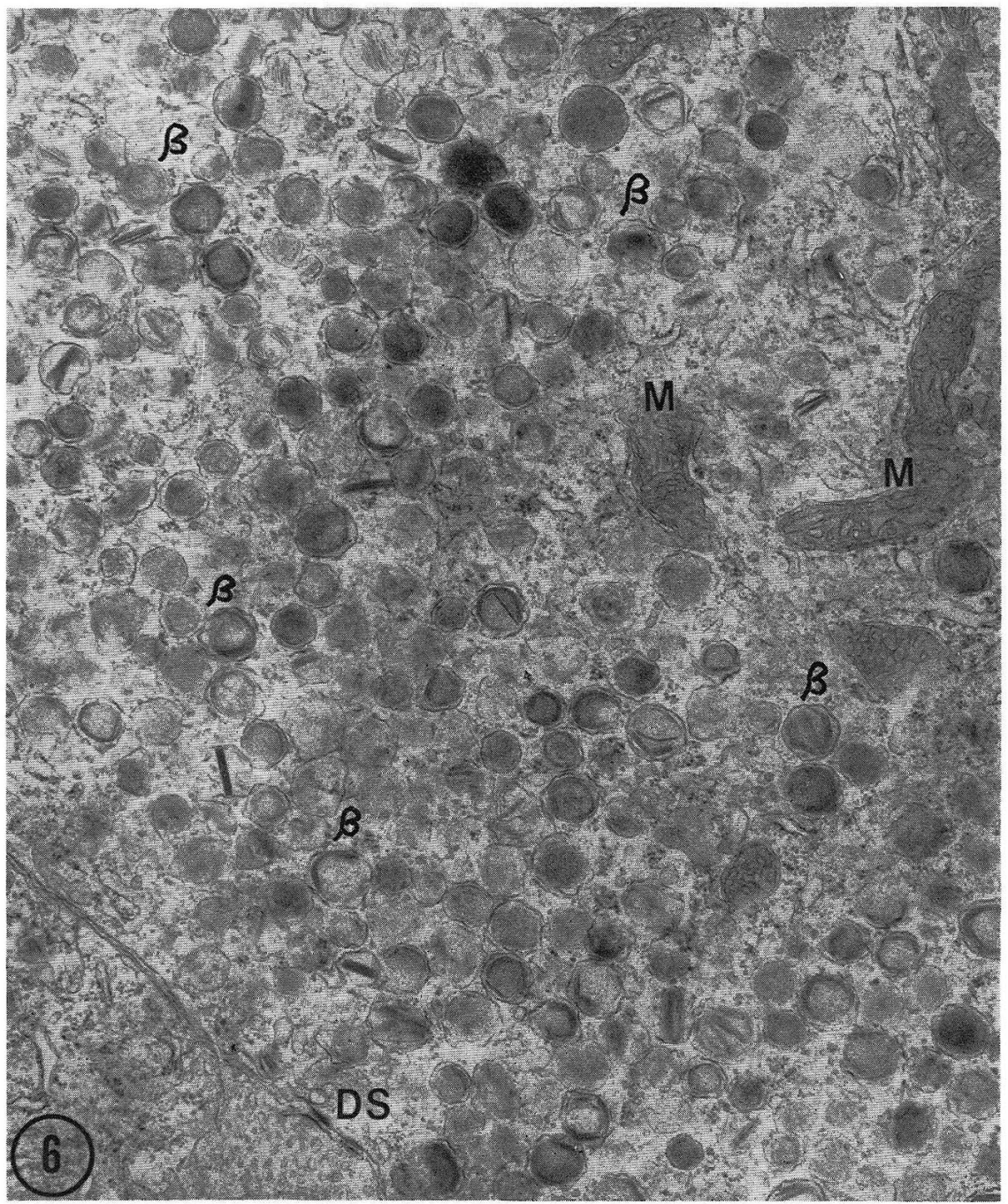

Fig. 6. A cytoplasmic portion of a B cell with numerous $\beta$-granules $(\beta)$ and some mitochondria $(M)$. The granules consist of a round membranous sac, a spherical homogeneous core of variable electron density which is usually traversed or bordered by needle- or barshaped crystalloids. $D S$ desmosome. $\times 20,000$ 
The secretory granule ( $\alpha$-granule) of the A cell is spherical and consists of a smooth limiting membrane and a dense spherical core encased in it. Between the two components a narrow electron lucent space is seen (Fig. 4, 5). The majority of the $\alpha$-granules measure about 200 to $400 \mathrm{~m} \mu$ in diameter but often appear two times or larger in size than ordinary ones. In the intercellular space between two islet cells, a $\alpha$-granule core is often seen contained in a concavity induced in the plasma membrane of the A cell (Fig. 5). Such findings may suggest the discharge of $\alpha$-granules by means of emiocytosis into the extracellular space.

\section{B cells}

Oval and elongated mitochondria with irregular cristae are scattered in the cytoplasm. Numerous membranous components of the rough surfaced endoplasmic reticulum are distributed throughout the cytoplasm, and in some places the parallel array of flattened sacs studded by ribosomes displays a lamellar pattern. Numerous free ribosomes, which for the most part aggregate into clusters, and a considerable number of glycogen particles are found (Fig. 6, 8, 9). The Golgi apparatus of $\mathrm{B}$ cells consists of elongated lamellae, numerous vesicles and sparse vacuoles. As in the A cells, ultrastructural findings which suggest the formation of the secretory granules in the Golgi complex have been demonstrated also in B cells. Namely, in the distended parts of the Golgi lamellae, electron dense granules probably corresponding to the precursors of the secretory granule have been observed (Fig. 7). Besides the abovementioned organelles, smooth surfaced vesicles are found throughout the cytoplasm.

The secretory granules ( $\beta$-granules) of B cells are distributed throughout the cytoplasm and characterized

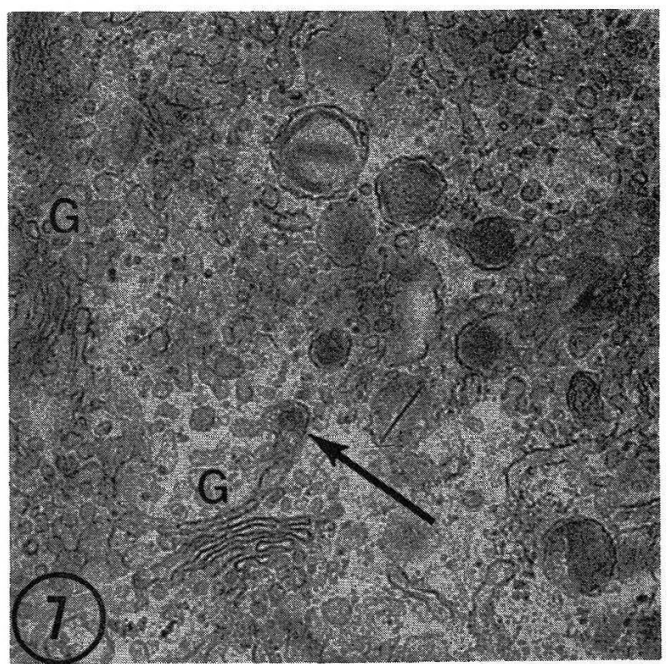

Fig. 7. Golgi complex $(G)$ of a B cell. Near the complex are seen small immature $\beta$-granules whose crystalloid structure is not distinct. In the bulbously dilated end of an elongated Golgi cisterna a minute dense granule $(\uparrow)$ is encased, suggesting the $\beta$-granule formation in the Golgi complex. $\times 25,000$ by an extensive polymorphism. A spherical membranous sac covers a spherical core consisting of a homogeneous substance of variable electron density and a number of bar or needle-shaped crystalloids of high density. The electron lucent space between the limiting membrane and the core is in general very narrow and inconspicuous. When the spherical homogeneous core is high in electron density, the crystalloid structures are less conspicuous. At high magnification it becomes obvious that the bar-shaped crystalloids consist of closely packed bundles of needle-shaped oriented in parallel (Fig. 8). The topographical relationship between the homogeneous substance and the crystalloids is variable, but roughly two patterns can be classified: 1) The crystalloids traverse the core through the middle as seen in Figure 8. 2) The crystalloids 
are disposed in straight or curved lines in the border of the homogeneous substance of the core as seen in Figure 9. In the latter case the crystalloids may form a polygonal, ring- or horseshoe-shaped pattern completely or incompletely surrounding the homogeneous core. The above mentioned two patterns may appear usually mixed in

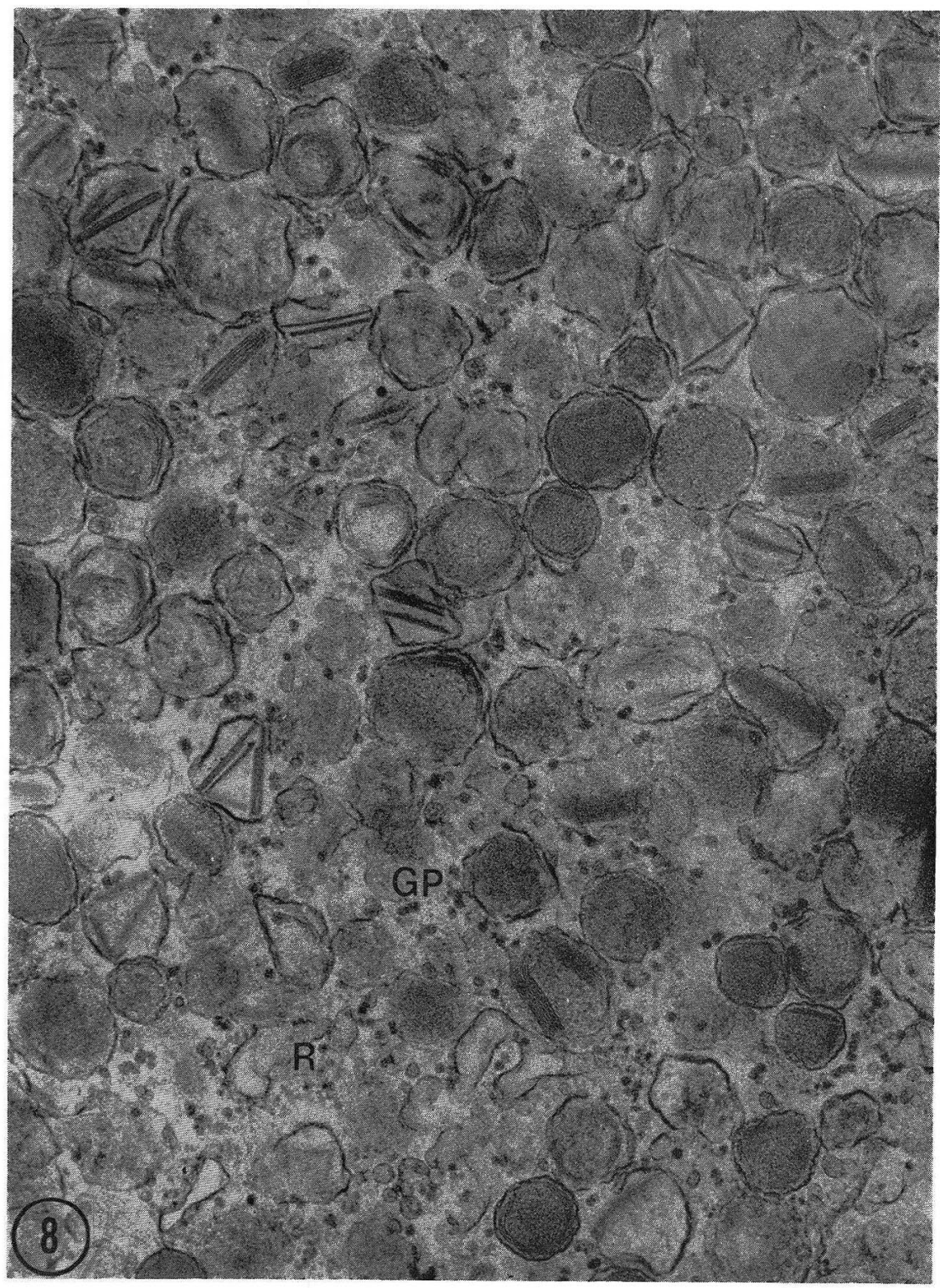

Fig. 8. A cytoplasmic portion of the B cell. In this portion, most $\beta$-granules contain the needle- or bar-shaped crystalloids traversing the homogeneous core through the middle, in several directions. Among these granules a considerable amount of glycogen particles $(G P)$, ribosomes $(R)$ and smooth vesicles are seen. $\times 45,000$ 
various proportions in one and the same B cell. The homogeneous core and the crystalloids seem to be in an intimate genetical relationship; the crystalloid cores may originate from the material of the homogeneous core. Sometimes the crystalloids are faintly manifested in the homogeneous core and sometimes they show only a weak fibrillar appearance (Fig. 6). The amounts of the homogeneous and the crystalloid core seem to be complementary to each other. When the crystalloid cores are hardly distinguishable from the considerably dense homogeneous matrix, $\beta$-granules may appear like $\alpha$-granules. Among $\beta$-granules there occur not infrequently those in which the limiting membrane is discontinuous and the cores have become faint. Such findings probably suggest the intracytoplasmic dissolution of $\beta$-granules.

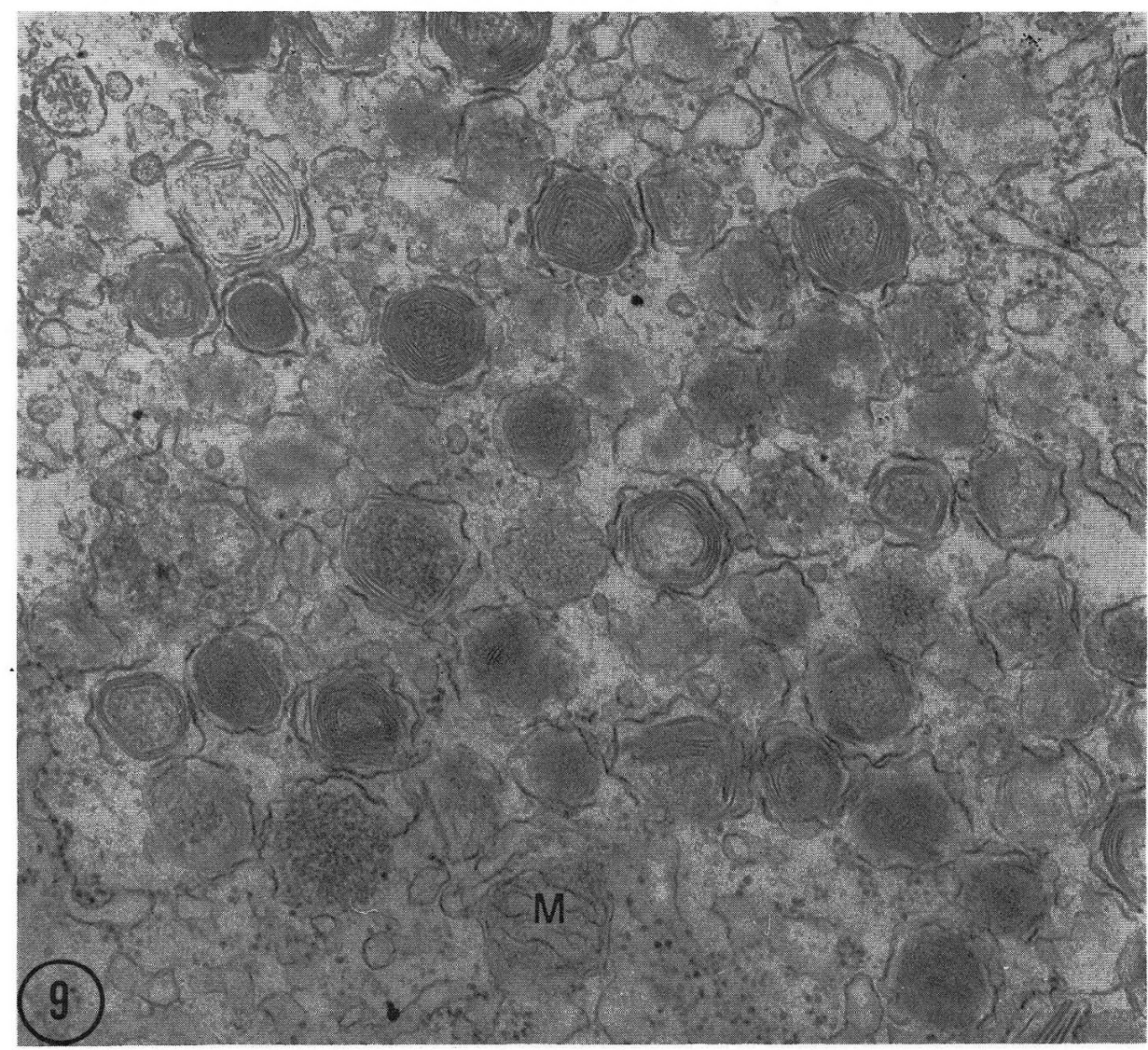

Fig 9. A cytoplasmic portion of the B cell. In this portion, most $\beta$-granules contain polygonal, circular or semicircular lamellae of crystalloids bordering the homogeneous core. Also, $\beta$-granules with a discontinuous membrane sac and a faint and indistinct core are observed as seen also in Figure $8 M$ mitochondrion. $\times 45,000$

\section{D cells}

Rod-shaped and elongated mitochondria with irregular cristae are scattered among other organelles. Cisternae of the rough surfaced endoplasmic reticulum are relatively few and ribosomes attached on the limiting membrane of the cisternae are 
in general sparse, showing an irregular arrangement. Free ribosomes are mostly aggregated in small clusters and glycogen particles are randomly scattered in the cytoplasm. One of the most conspicuous characteristics of D cells consists in that there appear in the cytoplasm among $\delta$-granules a large amount of vesicles and tubules of the smooth surfaced endoplasmic reticulum. They are of varying shapes and sizes and occupy the cytoplasmic areas between $\delta$-granules. D cells generally contain relatively numerous secretory granules ( $\delta$-granules), so that the cytoplasm is filled up by closely packed secretory granules. The $\delta$-granules consist of a spherical membrane

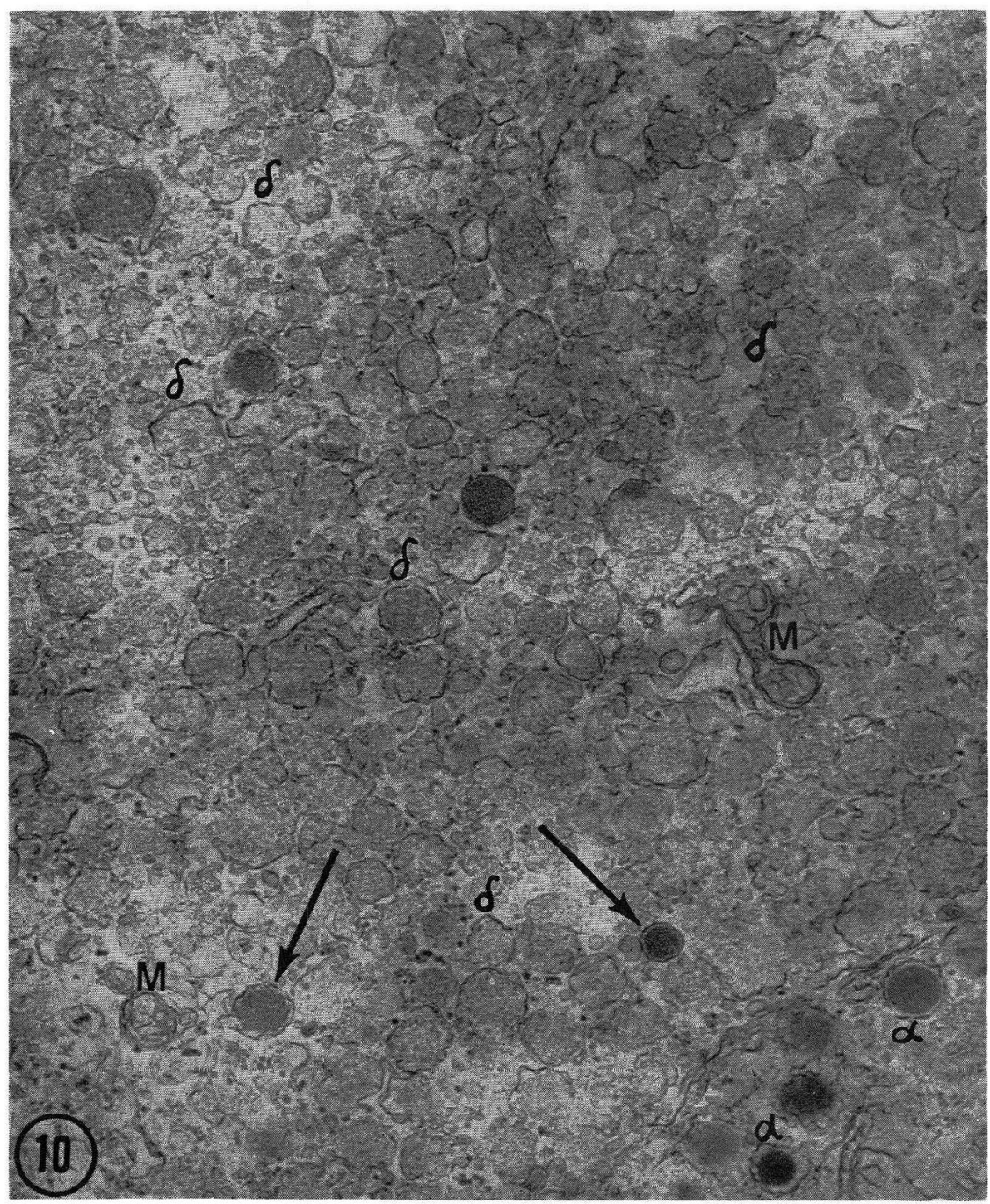

Fig. 10. A cytoplasmic portion of a D cell containing numerous $\delta$-granules $(\delta)$ of low electron density and coarse texture, abundant smooth vesicles and tubules and glycogen particles. Among the ordinary $\delta$-granules, a few smaller granules with a denser core and a clear narrow halo $(\uparrow)$ are seen which they resemble $\alpha$-granules $(\alpha)$ found in the right hand corner of the bottom, $M$ mitochondria. $\times 22,500$ 
sac and a closely attached core so that no clear space is present between the two components. The core or matrix of $\delta$-granules shows in general a coarse texture, appearing finely granular or flocculent. Generally $\delta$-granules are less electron dense than $\alpha$ - and $\beta$-granules, though considerably variable in density according to individual granules. Among the ordinary granules there appear in most D cells a small number of dense granules which, like $\alpha$-granules, consist of a smooth membrane sac and a spherical core of a high electron density with a narrow empty space between the two (Fig. 10, 11, 13). These granules which will be called in this paper " $\delta$-granules

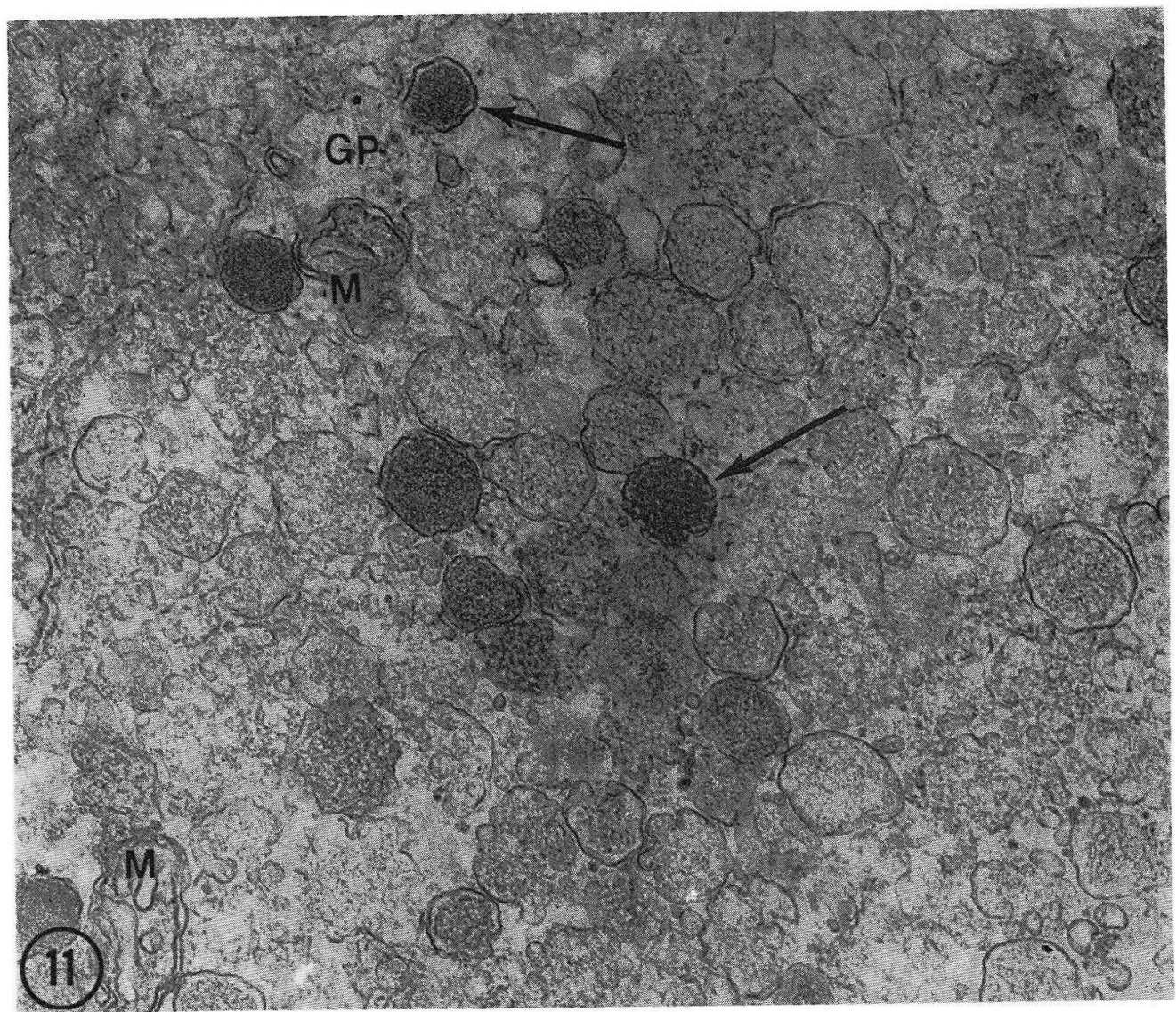

Fig. 11. Higher magnification of $\delta$-granules. They consist of a round membrane sac closely encircling a finely granular or flocculent core of more or less low density. Between the ordinary $\delta$-granules and the smaller ones $(\uparrow)$ with a dense granule core and a narrow empty halo there may be seen intermediary forms of various electron densities. Among the $\delta$-granules numerous smooth vesicles and tubules as well as glycogen particles $(G P)$ are seen. Notice also the $\delta$-granules with interrupted membrane sacs. $M$ mitochondria. $\times 45,000$

of varied type" are in general more or less smaller than the ordinary $\delta$-granules, and between these two types there are intermediary forms as seen in Figures 10 and 11. The varied type $\delta$-granules with a dense core seem to be younger ones in which the core may gradually decrease in electron density as the granules grow, simultanously 
acquiring coaser texture of a flocculent appearance. The $\delta$-granules are variable in size measuring approximately 200 to $400 \mathrm{~m} \mu$ in diameter. Round dense material
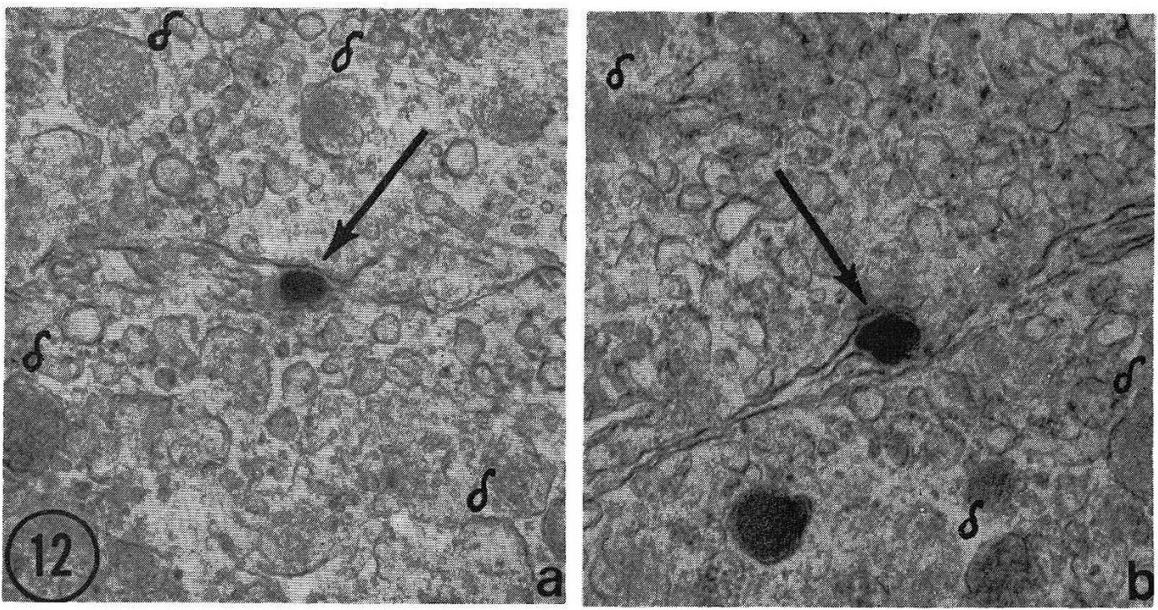

Fig. 12. a and $\mathbf{b}$. A dense granule core $(\uparrow)$ discharged probably by means of the emiocytotic mechanism into the intercellular space between two D cells. In the D cells $\delta$-granules $(\delta)$ and smooth vesicles and tubules are seen. $\times 28,300$

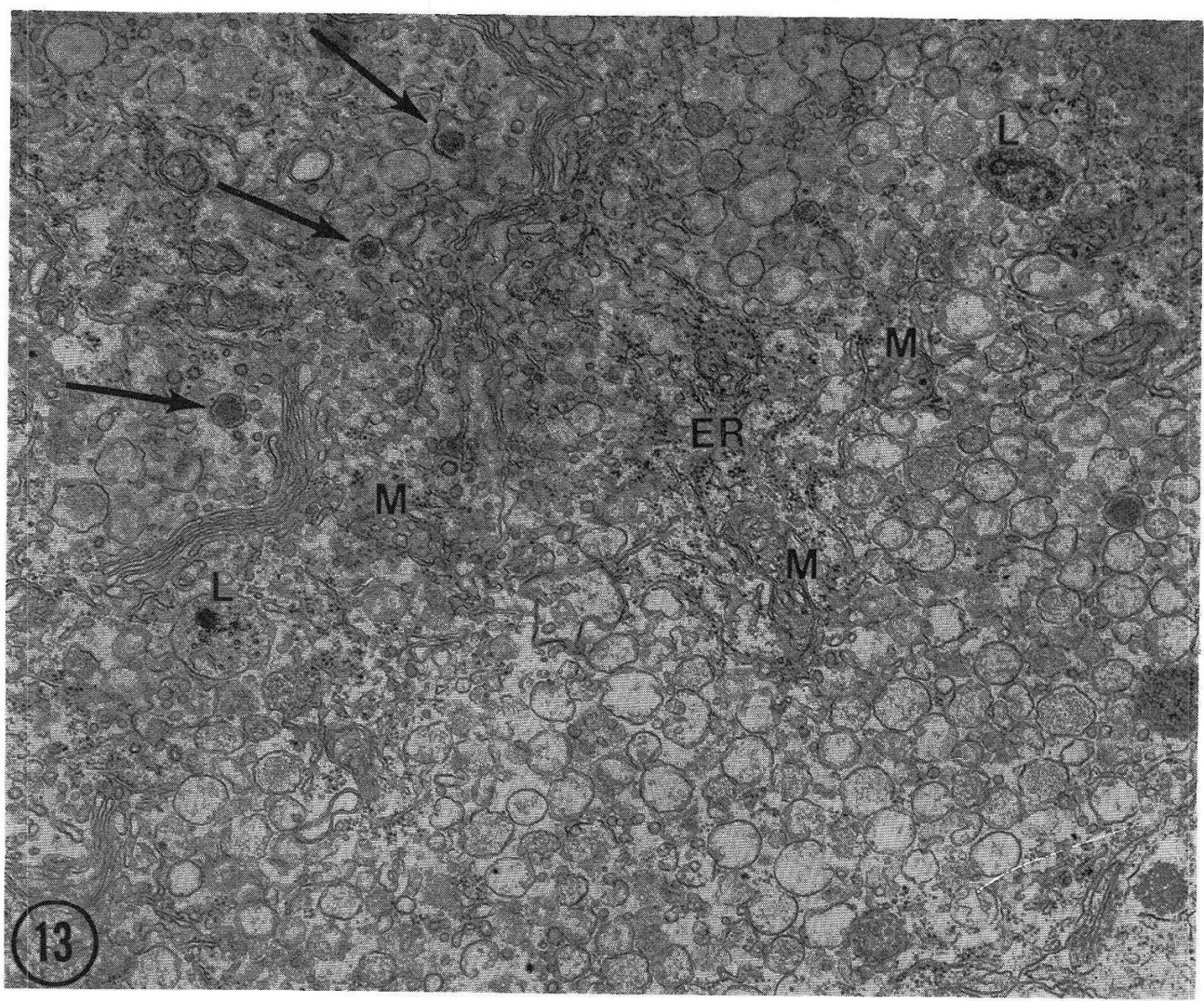


similar to the core of the rare $\delta$-granules is occasionally found in a concavity of the

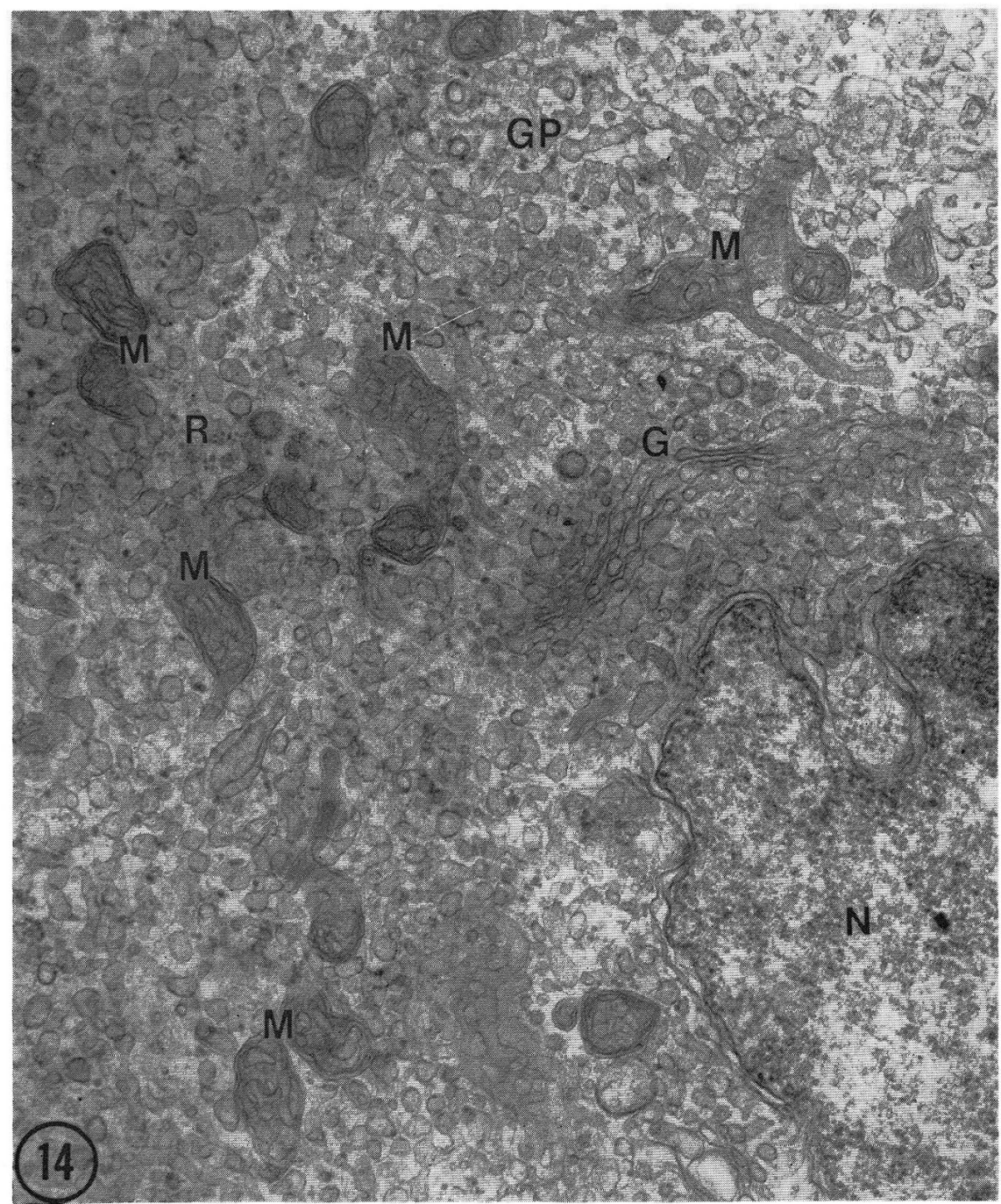

Fig. 14. The nucleated portion of an islet cell containing no secretory granules. Near the nucleus $(N)$ are observed the Golgi complex $(G)$ and numerous mitochondria $(M)$. In the cytoplasm, besides ribosomes $(R)$ and glycogen particles $(G P)$, abundant tubules and vesicles of the agranular endoplasmic reticulum are closely arranged, which suggest that this cell may correspond to a D cell. $\times 28,300$

Fig. 13. A portion of a D cell with smaller and clearer $\delta$-granules, among which numcrous smooth vesicles and tubules, are seen. In the dilated portions of the Golgi cisternae, electron dense minute granules $(\uparrow)$ are seen. Near the Golgi complex small, probably immature secretory granules $(\uparrow)$ are observed, which coincide in fine structure with the small and dense type of $\delta$-granules shown in Figures 10 and 11 . Numerous mitochondria $(M)$, granular endoplasmic reticulum $(E R)$, free ribosomes and lysosomes $(L)$ are present near the Golgi complex. $\times 24,000$ 
intercellular space between two D cells (Fig. 12), suggesting a possible discharge of the varied type $\delta$-granules by means of the emiocytotic process. However, no finding suggestive of the emiocytotic extrusion of the ordinary $\delta$-granules have been obtained. Among D cells there occur occasionally islet cells whose granules, though very similar to $\delta$-granules, are smaller and less dense than the latter (Fig. 13). The secretory granules of these D-like cells, measuring about $230 \mathrm{~m} \mu$ in diameter and consisting of a membrane sac and an electron lucent flocculent content, are mingled with many

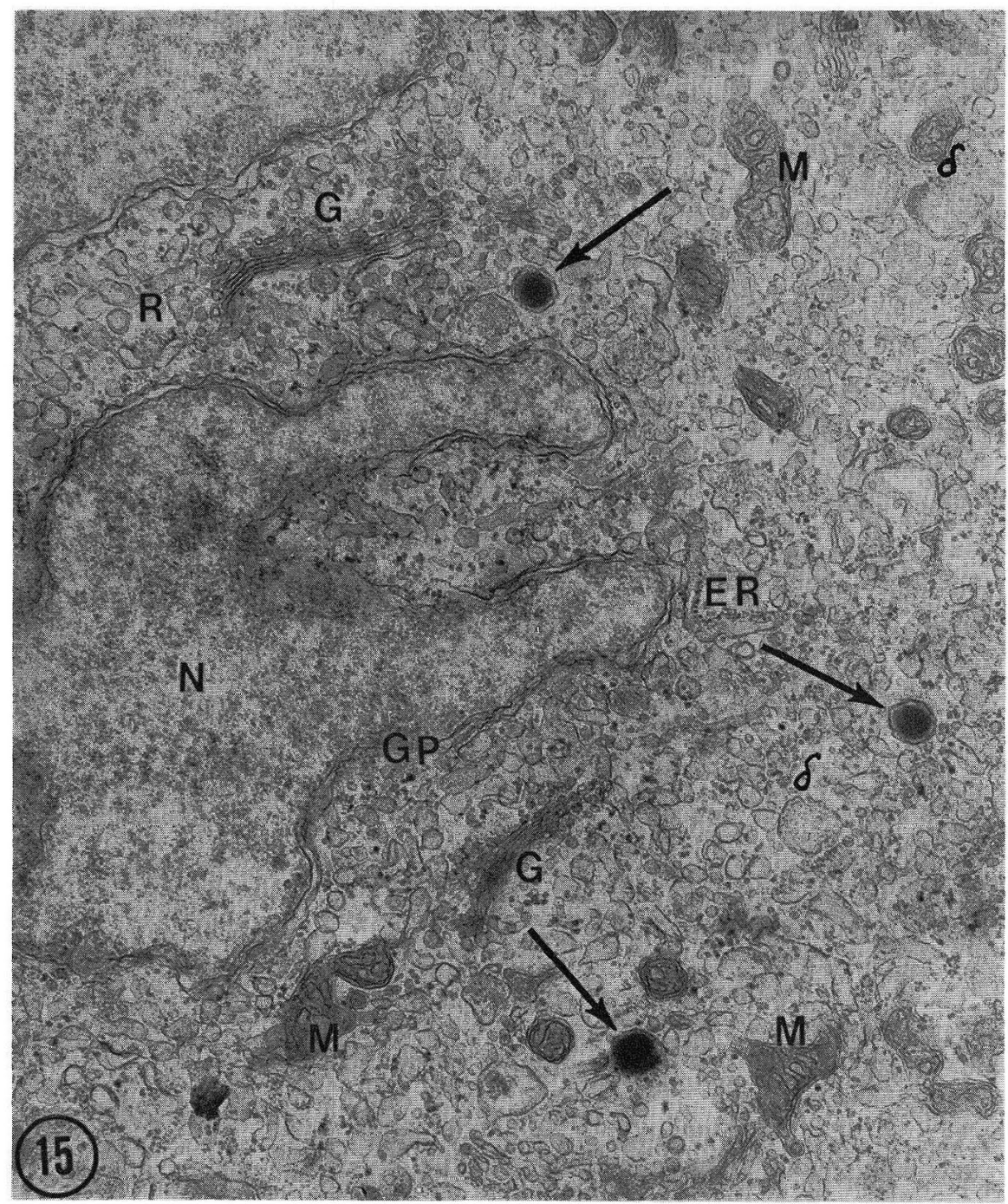

Fig. 15 The nucleated portion of a D cell containing sparse $\delta$-granules of low density $(\delta)$; the small $\delta$-granules with a dense spherical core and a narrow empty halo ( $\uparrow$ ) are conspicuous near the nucleus $(N)$. Abundant smooth vesicles and tubules suggest also that this islet cell is a D cell. $E R$ granular endoplasmic reticulum, $G$ Golgi complex, $G P$ glycogen particle, $R$ free ribosomes. $\times 22,500$ 
membrane sacs appearing almost empty. In addition, these cells contain a large amount of vesicular components of the smooth surfaced endoplasmic reticulum among the secretory granules. Therefore, these cells may be identified as D cells containing smaller and clearer $\delta$-granules. In one of these cells illustrated in Figure 13, the Golgi complex is seen associated with numerous mitochondria, cisternae of the granular endoplasmic reticulum and clusters of free ribosomes, and it consists of well-developed lamellae and numerous vesicles. Near the Golgi complex a number of small membrane-bound granules containing a core of high density are found which seem to be identical with the above mentioned varied type $\delta$-granules. In the dilated portion of the Golgi lamellae minute dense granules are seen which probably represent the precursors of the secretory granules. This suggests the formation of the secretory granules in the Golgi complex, and the above mentioned small granules with a dense core near the Golgi complex may be young immature secretory granules. This finding may provide further support for the presumption that the varied type $\delta$-granules represent younger granules.

Further, among D cells, are occasionally seen islet cells which, like the cell illustrated in Figure 14, contain almost no secretory granules. The entire cytoplasm is closely packed with abundant vesicles and tubules of the agranular endoplasmic reticulum. Also the Golgi complex, mitochondria of variable shapes, clusters of free ribosomes, glycogen particles and scant cisternae of the granular endoplasmic reticulum are recognized. The occurrence of the abundant vesicles and tubules of the agranular endoplasmic reticulum is regarded, as mentioned above, as characteristic of the D cell in the Carassius. Furthermore, in a similar islet cell illustrated in Figure 15 , a small number of secretory granules identical with $\delta$-granules are found among which are mingled a few granules corresponding to the varied type. On the basis of the above findings the islet cells in question are believed to be $\mathrm{D}$ cells completely or incompletely lacking in secretory granules, and are presumed to correspond to the "agranular" or "clear" cells observed by light microscopy.

\section{Discussion}

As a detailed review of the literature concerning the classification of islet cells in fishes can be found in the paper of WATANABE (1960), we will cite only recent works. It was WATANABE (1960) who for the first time exactly classified teleostean (carp) islet cells into A, B and D cells. After him Falkmer (1961) identified only A and B cells in Cottus scorpius and Sivadas (1964) only B cells in Tilapia mossambica. In cartilaginous fishes KERN (1964) has recently confirmed the early result of THOMAS (1940) on the occurrence of A, B and D cells, whereas FujitA (1962) found X cells in Chimaera besides these cells.

In the islets of the Carassius observed in the present study A, B and D cells have been identified both by light and electron microscopy. Besides these, "clear" or "agranular" cells have been identified in small numbers by light microscopy and are presumed to correspond to D cells completely or incompletely lacking in $\delta$-granules as electron microscopy revealed a gradual transition between the typical D cells and the agranular appearing cells.

Hellman and Hellerström (1960) have for the first time divided the A cell into argyrophil $A_{1}$ and non-argyrophil $A_{2}$ cells in the preparations of duck and chick islets 
stained by their modification of Davenport's impregnation method. Thereafter, their research group has revealed in a large variety of vertebrate species the existence of $\mathrm{A}_{1}$ cells and proved that the glucagon-producing cells must be non-argyrophil $\mathrm{A}_{2}$ cells; the nature of the $A_{1}$ cell remains unsolved. Recently, however, Fujita (1964, 1966), Epple (1965), Cavallero and Solcia (1964), Solcia and Sampietro (1964, 1965), Munger, Caramia and Lacy $(1965)$ and Kobayashi $(1966,1969)$ have demonstrated that the silver positive $A_{1}$ cells are nothing but $D$ cells.

Also in the present study on the pancreatic islets of Carassius carassius longsdorfii, the argyrophil islet cells have likewise been demonstrated by means of the silver impregnation method of Hellman and Hellerström, and on the basis of the morphological evidence that the shape, distribution and number of these argyrophil cells coincide with those of $\mathrm{D}$ cells the authors came to the opinion that the argyrophil islet cells are identical with D cells also in the islets of the Carassius.

According to the rough calculation of WATANABE (1960) in some teleostean fish islets the numerial A:B:D ratio is 45:50:5 in the carp and 20:60:20 in some marine teleosts (Platycephalus indicus, Pagrosomus major and Mylio macrocephalus). The present study has shown that the ratio of roughly calculated numbers of $A, B, D$ and "clear" of "agranular" cells in the Carassius islets is approximately 25: 50:15: 10. Taking into account that the last type of cells were identified by electron microscopy to be the same as D cells, the ratio of the A, B and D cell population can ultimately be assumed to be $25: 50: 25$. This essentially corresponds to the cell population in marine teleostean fishes reported by WATANABE (1960) though it reveals a larger population of the $\mathrm{D}$ cell in Carassius carassius. The $\mathrm{A} / \mathrm{B}$ ratio in the tunny fish islets was reported by Planas and Garcia (1964) to be $80: 20$ or $64: 36$, thus the A cell population being remarkably larger in the tunny fish than in the carp and Carassius. The A:B:D ratio in the islets of the cartilaginous fishes has been reported by THOMAs (1940) and KERN (1964).

The first electron microscopic study on the islet cells in the teleost was carried out by Watanabe (1960) with the carp. His description is concerned with the ultrastructures of secretory granules of A and B cells but not at all with those of D cells. According to his observations, $\alpha$-granules are extensively polymorphous, consisting of a smooth membrane-bound sac and a spherical or crystalloid core, while $\beta$-granules consist of a smooth membrane-limited sac and a spherical or elliptic core of high electron density. Later, TiтLBACH (1966) observed the carp islets under the electron microscope and pointed out that $\alpha$-granules, unlike WATANABE's description had a homogeneous spherical or oval core of high electron density closely encased by the limiting membrane, while $\beta$-granules were polymorphous and contained in the smooth membrane-bound sac a finely granular osmiophil core in which needle-shaped crystalloids oriented in various directions were identified. It is thus obvious that the $\alpha$-granules described by WATANABE correspond to the $\beta$-granules described by TiTLBACH and vice versa. This controversy concerning the ultrastructure of $\alpha$ - and $\beta$-granules of the carp has been solved by the recent electron microscope study of FALLER and LANGE (1969) on the same material. They used alternate thick and thin sections to compare cells in stained preparations with the cells under the electron microscope, and confirmed that the granules of the B cell were polymorphous as revealed by TitLBACH (1966) and pointed out that WATANABE (1960) had erroneously taken A cells for B cells 
and vice versa.

In Carassius carassius longsdorfii, $\alpha$-granules consist, like those of other animal species, of a spherical core of high electron density encased closely in a smooth membranous sac with a slight space between both. The $\beta$-granules of the Carassius consist of a smooth membrane sac and a spherical core which is composed of a homogeneous substance of variable electron density and a number of bar or needle-shaped crystalloids of high density which traverse or surround the former. The electron lucent space between the sac and the core is narrow or inconspicuous. Therefore, the ultrastructural features of $\alpha$ and $\beta$-granules in the Carassius closely resemble those of the corresponding granules of the carp described by TітьвACH (1966). Carassius and carp are related species of fishes, both belonging to Cyprinidae. Concerning the ultrastructural morphology of these granules, LACy (1961) and SAto, Herman and Fitzgerald (1966) have noted that while $\alpha$-granules are uniform in shape and density in almost all species, $\beta$-granules, which represent according to their opinion the storage form of insulin, show remarkable species difference in their ultrastructure. It may be rather noteworthy that the ultrastructures of $\beta$-granules almost completely conincide in carp and Carassius. Lacy (1957a, b) Sato, Herman and Fitzgerald (1966), and BJörKMAN and HELLMAN (1967) have suggested that the morphological variability of $\beta$-granules may possibly reflect differences in the molecular or primary structures of either insulin or its associated binding protein. If so, the finding that the ultrastructures of the $\beta$-granules in the carp and Carassius are similar, may indicate a molecular identity of the insulin stored in the B cells of these species.

The ultrastructure of the $\delta$-granule, like that of the $\alpha$-granule, little varies among vertebrate species, shhowing a spherical cutline containing a flocculent matrix of low density (SAto, HeRman and FitzGerald, 1966). In his electron microscope study of the teleostean pancreas, TiтLBACH (1966) has confirmed that most of the $\delta$-granules of the carp consist of a limiting membrane which is often discontinuous and an osmiophil flocculent content of low density. He also found a few granules with a spherical dense core. The $\delta$-granules of the Carassius descrived in the present study resemble those of the carp. It has already been discussed above that a few small granules with a core of high density intermingled with the typical $\delta$-granules are regarded as immature $\delta$-granules. D cells are characterized not only by the typical $\delta$-granules but also by numerous, closely packed vesicles and tubules of the agranular endoplasmic reticulum. These structures serve as the criteria for idintifying the D cells in the case they are completely or partially lacking in typical $\delta$-granules. It has been revealed by several authors that D cells of various vertebrate species especially of mammals, cannot be well preserved after a single fixation with osmic acid. The D cells of the Carassius, however, were relatively well fixed with osmic acid alone. Recently it has been proposed by a number of authors that $\delta$-granules fixed with glutaraldehyde followed by postfixation with osmic acid show better results with an increase in density of their matrix or core (Titlback, 1967; Like, 1967; Kobayashi and Fujita, 1969; ShIBASAKI and ITo, 1969). In the present study, however, the authors have not applied to the Carassius islets successive fixations with glutaraldehyde and osmic acid.

The possible functional significance of $D$ cells has been discussed by several authors (see the review by FUJITA, 1968), and the possibility that they might produce a third hormone of the pancreas represents a current problem of endocrinology. 
Recently, LOMSKY, LANGLAND and VoRTel (1969) reported that they could demonstrate by means of the immunofluorescence technique the presence of gastrin in the $\mathrm{D}$ cells of normal mammalian pancreatic islets.

As for the formation of the secretory granules in the islet cells, many authors have obtained morphological evidence which supports the view that the Golgi complex may play a dominant part in granule formation (WINBORN, 1963; CARAMIA, 1963; Caramia, Munger and Lacy, 1965; Fujita and Matsuno, 1967; Kobayashi, 1966, 1969; Kobayashi and Fujita, 1969; Shibasaki and Ito, 1969). Especially Kobayashi (1969), in Xenopus, and SibASAKI and Iто (1969), in man, have confirmed the formation of the secretory granules within the Golgi complex in all islet cell types classified by electron microscopy. The present findings in the Carassius fully coincide with their conclusion, namely that in all islet cell types minute granules occurred in the dilated portions of the cisternae of the Golgi lamellae and seemed to be pinched off together with the membrane of the latter to form immature secrectory granules which were found in the vicinity of the Golgi complex. In the B cells the crystalloid structure was not yet recognized in the granule core of immature $\beta$-granules, and in D cells immature granules were characterized by a granule core of more compact texture and higher density than mature $\delta$-granules.

Concerning the mechanism of the release of secretory granules from islet cells, two processes have been proposed: 1) release by means of emiocytosis and 2) release by means of the intracytoplasmic dissolving of the specific granules followed by diacrine passage through the plasma membrane. As revealed by numerous authors (Lacy, 1961; Lazarus and Volk, 1962; Björkman, Hellerström and Hellman, 1963; Volk and Lazarus, 1964; Burton and Vensel, 1966; Machino, 1966; Machino, Sakuma and Onoe, 1966; Machino, Onoe and Sakuma, 1966; Machino and Sakuma 1967; Fujita and Matsuno 1967; Machino and Sakuma, 1968; Watari and Honma, 1968; Kobayashi and FujITA, 1969 and others), emiocytosis proceeds by the approach and fusion of the granule sac to the plasma membrane of the cell and by the opening of the fused portion of the membranes. In the present study the dense spherical cores of $\alpha$-granules and those of $\delta$-granules, which had probably been released by this type of secretion, were occasionally found in the extracellular space. The $\beta$-granules of the Carassius, however, did not show any signs of emiocytotic release. Granule release by the second mechanism has been described by many authors in the islet cells of several vertebrate species (Munger,1962; Björkman and Hellman, 1960; Munger, Caramia and Lacy, 1965; Schultrich, 1966; Lever and Findlay, 1966; Kobayashi, 1966, 1969; LegG 1967; SibASAKI and Ito 1969 and others). Shibasaki and Ito (1969) who have observed only the second type secretion in the normal human islet cells have mentioned the following as the usual pictures suggesting intracytoplasmic dissolving: 1) density decrease and faint configuration of the core, and 2) discontinuity and occasional disappearance of the membranous sac. Such findings suggesting the second means of granule release have been confirmed in all three types of islet cells of the Carassius islets but it is especially conspicuous in $\beta$-granules. Therefore, the $\beta$-granules of the Carassius are presumed to be principally released by intracytoplasmic dissolving, while $\alpha$ - and $\delta$-granules may be discharged partly by means of emiocytosis and partly by means of intracytoplasmic dissolving. The simultaneous occurrence of the two types of granule release does not seem to be exceptional in the islet cells. 


\section{Summary}

The islet of Langerhans of Carassius carassius longsdorfii (Temminck et Schlegel) has been observed by light and electron microscopy.

1. The islet tissue of the Carassius is concentrated into several spherical bodies embedded in the exocrine pancreas or in the mesentery. They are surrounded by a distinct connective tissue capsule, and richly supplied by blood capillaries.

2. By light microscopy, A, B and D cells are distinguished according to their staining reactions. The cells deserving the name of "clear" or "agranular" cells under the light microscope can be identified by electron microscopy as D cells containing no or few secretory granules. B cells form a network of cell cords throughout the islets, in the meshes of which A, D and "clear" cells are distributed. The population ratio of $\mathrm{A}: \mathrm{B}: \mathrm{D}$ cells comes to $25: 50: 25$ (of which 10 are the light microscopic "clear cells").

3. Argyrophil islet cells are demonstrated in the silver impregnated specimens and correspond in shape, distribution and number to the D cells.

4. Under the electron microscope the three islet cell types are distinguished by the specific ultrastructural features of their secretory granules. The D cells of the Carassius are further characterized by the abundant occurrence of the vesicles and tubules of the agranular endoplasmic reticulum.

5. The $\alpha$-granules of the Carassius (200-400 $\mathrm{m} \mu$ in diameter) consist of a membranous sac encasing a homogeneous spherical core of high electron density with a slight space between the two being characteristic. The $\beta$-granules of the Carassius (200-400 $\mathrm{m} \mu$ in diameter) closely resemble those of the carp (TiтLBACH, 1966), showing a membranous sac and a spherical core which is composed of a homogeneous substance and needle- or bar-shaped crystalloids; the electron lucent space between the sac and the core is inconspicuous. In the $\delta$-granules of the Carassius (200-400 $\mathrm{m} \mu$ in diameter), a round membrane sac is closely attached to a finely granular or flocculent core of low electron density. A few smaller and denser granules may occur among the ordinary $\delta$-granules and near the Golgi complex; they are regarded as immature $\alpha$ granules.

6. In the Carassius, the formation of secretory granules in the Golgi complex is evidenced in the three islet cell types. The release of secretory granules by means of emiocytosis is confirmed in A and D cells but not in B cells. Findings suggestive of the granule release by intracytoplasmic dissolution are obtained in all three islet cell types but especially conspicuously in B cells.

Acknowledgement. We are deeply indebted to Prof. Toshio Iтo for his encouragement and valuable discussions during this study.

\section{ギンブナのランゲルハンス島の光学および電子顕微鏡的観察（内容自抄）}

\section{ギンブナのランゲルハンス島を光学および電子顕微鏡によって観察した.}

1.フナの島組織は多数の球形小体をなして膵臓の外分泌部あるいは腸間膜の中に埋 没している，それらは明瞭な結合組織膜でおおわれ，豊富な毛細血管分布がある.

2. 光学顕微鏡では染色性によって A， B，D 細胞が識別される. “明調”あるいは 
“無顆粒細胞”とよばれる細胞は電子顕微鏡下に分泌顆粒がないか，あるいは極めて少な いD細胞と同定された。 $\mathrm{B}$ 細胞は島の内部に拡がる細胞索網を形成し，この網眼の中に A， D と明調細胞が分布する. A， B， D 細胞の数的比 A : B : D = 25: $50: 25$ (25の らち10は明調細胞が占める).

3. 鍍銀法で証明される銀好性細胞はその形，分布，数において D細胞と一致する.

4. 電子顕微鏡によって分泌顆粒の超微構造の特性から 3 種の島細胞が識別される. フナの D 細胞はさらに小胞ないし小管状の滑面小胞体を豊富に含むことが特徴的である。

5. フナの顆粒（直径 $200 \sim 400 \mathrm{~m} \mu$ ) ほ限界膜の中に均質性，高電子密度の球形の心を 入れ，両者の間には狭い間隙がある. $\beta$ 顆粒 $(200 \sim 400 \mathrm{~m} \mu)$ はコイ (TiTLBACH, 1966) のそれに似ており，限界膜の内部に均質性の物質からなる球形の心と針状あるいは棒状

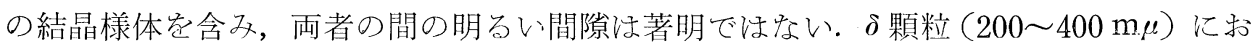
いては円形の限界膜は低電子密度で微細顆粒状ないし雲繁状の心に密接する. 通常の $\delta$ 顆粒に混じて少数の小さくて電子密度が高い顆粒がゴルジ装置の近くに出現することが 多いが，未熟な $\delta$ 顆粒と思われる。

6. ゴルジ装置における分泌顆粒の形成がフナにおいては 3 種の島細胞で証明された. 開口分泌 (emiocytosis) による顆粒放出はAとD細胞で確認されたが，B細胞では確か められなかった．細胞内溶解による顆粒の放出を走唆する所見が 3 種の島細胞でみられ たが，とくにB細胞で著明であった。

\section{References}

Björkman, N. and B. Hellman: Ultrastructure of the islets of Langerhans in the duck. Acta anat. 56: 348-367 (1964).

- : Morphological characteristics of the secretory granules in pancreatic $\beta$-cells from species with identical primary structures of insulin. Experientia 23: 721-722 (1967).

Björkman, N., C. Hellerström and B. Hellman: The ultrastructure of the islets of Langerhans in normal and obese-hyperglycemic mice. Z. Zellforsch. 58: 803-819 (1963).

Burton, R. P. and W. H. Vensel: Ultrastructural studies of normal and alloxan-treated islet of the pancreas of the lizard, Eumeces fasciatus. J. Morphol. 118: 91-119 (1966).

Caramia, F.: Electorn microscopic description of a third cell type in the islets of the rat pancreas Amer. J. Anat. 12: 53-64 (1963).

Caramia, F., B. L. Munger and P. E. Lacy: The ultrastructural basis for the identification of cell types in the pancreatic islets. I. Guinea pig. Z. Zellforsch. 67: 533-546 (1965).

Cavallero, C. and E. Solcia: Cytologic and cytochemical studies on the pancreatic islets (ed. by) Brolin, S. E., B. Hellman and H. Knutson: The structure and metabolism of the pancreatic islets. Proc. 3. Wenner-Gren Center Int. Sympos. Uppsala and Stockholm, 1963. London, Pergamon Press, 83-97 (1964).

Epple, A.: Weitere Untersuchungen über ein drittes Pankreashormon. Verh. Deut. Zool. Ges. 459470 (1965).

Falkmer, S.: Histological and histochemical investigations of the pancreatic islet tissue. In: Experimental diabetes research in fish. Acta endocrinol. (Kbh.) Suppl. 59. 1961 (p. 7-27).

Falkmer, S. and L. Winbladh: An investigation of the pancreatic islet tissue of the hagfish (Myxine glutinosa) by light and electron microscopy. In: (ed. by) S. E, Brolin, B. Hellman and H. Knutson: The structure and metabolism of the pancreatic islet. Proc. Int. Wenner-Gren Sympos., Uppsala 
and Stockholm 1963. Oxford, Pergamon Press, 1964 (p 17-32).

Faller, A. und R. Lange: Kombinierte licht- und elektronenmikroskopische Analyse des Zellbildes in den Langerhansschen Inseln des Karpfens. Arch. histol. jap. 31: 73-80 (1969).

Fujita, H. and Z. Matsuno: Some observations on the fine structure of the pancreatic islet of rabbits, with special reference to $B$ cell alteration in the hypoglycemic state induced by alloxan treatment. Arch. histol. jap. 28: 383-398 (1967).

Fujita, T.: Über das Inselsystem des Pankreas von Chimaera monstrosa. Z. Zellforsch. 57: 487-494 (1962).

-: The identification of the argyrophil cells of pancreatic islets with D-cells. Arch. histol. jap. 25: 189-197 (1964).

: D-Zellen der Pankreasinseln beim Diabetes mellitus mit besonderer Berücksichtigung ihrer Argyrophilie. Z Zellforsch. 69: 363-370 (1966).

: D cell, the third endocrine element of the pancreatic islet. Arch. histol. jap. 29: 1-40 (1968).

Hellman, B. and C. Hellerström: The islets of Langerhans in ducks and chickens with special reference to argyrophil reaction. Z. Zellforsch. 52: 278-290 (1960).

Kern, H.: Untersuchungen über das Pankreas einiger Selachier mit besonderer Berücksichtigung des Inselorgans. Z. Zellforsch. 63: 134-154 (1964).

Kobayashi, K.: Electron microscope studies of the Langerhans islets in the toad pancreas. Arch. histol. Jap. 26: 439-482 (1966).

- Light and electron microscopic studies on the pancreatic acinar and islet cells in Xenopus laevis. Gunma J. Med. Sci. 17/18: 60-103 (1969).

Kobayashi, S. and T. Fujita: Fine structure of mammalian and avian pancreatic islets with special reference to D cells and nervous elements. Z. Zellforsch. 100: 340-363 (1969)

Lacy, P, E.: Electron microscopic identification of different cell types in the islets of Langerhans of the guinea pig, rat, rabbit and dog. Anat. Rec. 128: 255-268 (1957a).

: Electron microscopy of the normal islets of Langerhans. Studies in the dog, rabbit, guinea pig and rat. Diabetes 6: 498-507 (1957b).

: Electron microscopy of the beta cell of the pancreas. Amer. J. Med. 31: 851-859 (1961).

Lazarus, S. S. and B. W. Volk: The pancreas in human and experimental diabetes. New YorkLondon, Grune \& Stratton, 1962.

Legg. P. G.: The fine structure and innervation of the beta and delta cells in the islets of Langerhans of the cat. Z. Zellforsch. 80: 307-321 (1967).

Lever, J. D. and J. A. Findlay: Similar structural bases for the storage and release of secretory material in adreno-medullary and $\beta$ pancreatic cells. Z. Zellforsch. 74: 317-324 (1966).

Like, A. A.: The ultrastructure of the secretory cells of the islets of Langerhans in man. Lab. Invest. 16: 937-951 (1967).

Lomsky, R., F. Langrand and V. Vortel: Immunohistochemical demonstration of gastrin in mammalian islets of Langerhans. Nature 223: 618-619 (1969).

Luft, J. H.: Improvements in epoxy resin embedding methods. J. biophys. biochem. Cytol. 9: 409-414 (1961).

Machino, M.: Electron microscope observations of pancreatic islet cells of the early chick embryo. Nature 210: 853-854 (1966).

Machino, M., T. Onoe and H. Sakuma: Electron microscopic observations on the islet alpha cells of the domestic fowl pancreas. J. Electronmicrosc. 15/4: 23-30 (1966).

Machino, M. and H. Sakuma: Electron microscopy of islet alpha cells of domestic fowl. Nature 214: 808-809 (1967).

chick embryos. J. Endocrinol. 40: 129-130 (1968).

Machino, M., H. Sakuma and T. Onoe: The fine structure of the D cells of the pancreatic islets in the domestic fowl and their morphological evidence of secretion. Arch. histol. jap. 27: 407-418 (1966).

Munger, B. L.: The secretory cycle of the pancreatic islet alpha cell. Lab. Invest. 11: 885-901 (1962). 
Munger, B. L., F. Caramia and P. E. Lacy: The ultrastructural basis for the identification of cell types in the pancreatic islets. II. Rabbit, dog and opossum. Z. Zellforsch. 67: 776-798 (1965).

Östberg, H., C. Hellerström and H. Kern: Studies on the $A_{1}$-cells in the endocrine pancreas of some cartilaginous fishes. Gen. comp. Endocrinol. 7: 475-481 (1966).

Planas, J. and F. Garcia: New data regarding the pancreatic islets in the tunny fish. Acta anat. 57: 185-191 (1964).

Sato, T., L. Herman and P. J. Fitzgerald: The comparative ultrastructure of the pancreatic islets of Langerhans. Gen. comp. Endocrinol. 7: 132-157 (1966).

Schultrich, S.: Elektronenmikroskopische Beiträge zum Bau des menschlichen Inselapparates. Endokrinologie 49: 105-125 (1966).

Shibasaki, S. and T. Ito: Electron microscopic study on the human pancreatic islets. Arch. histol. jap. 31: 119-154 (1969).

Sivadas, P.: The occurrence of $\beta$-cells in the islets of Langerhans of Tilapia mossambica (Peters) (Teleostei). Gen. comp. Endocrinol. 4: 295-298 (1964).

Solcia, E. e R. Sampietro: Istochimica dei secretormonali nelle isole pancreatiche normali e nei tumori insulari. Rivista Patol. clin. speriment. 5: 427-437 (1964). 65: 131-138 (1965).

Thomas, T. B.: Islet tissue in the pancreas of the elasmobranchii. Anat. Rec. 76: 1-17 (1940).

Titlbach, M.: Feinstruktur der Zellen der Langerhansschen Inseln bei Cyprinus carpio L. Z. mikrosk. -anat. Forsch. 75: 184-197 (1966).

-: Licht- und elektronenmikroskopische Untersuchungen der Langerhansschen Inseln von Eidechsen (Lacerta agilis L., Lacerta viridis Laurenti). Z. Zellforsch. 83: 427-440 (1967).

Volk, B. W. and S. S. Lazarus: Ultrastructure of pancreatic B cells in severely diabetic dogs. Diabetes 13: 60-68 (1964).

Watanabe, A.: Histologische, cytologische und elektronenmikroskopische Untersuchungen über die Langerhansschen Inseln der Knochenfische, insbesondere des Karpfens. Arch. histol. jap. 19: 279-330 (1960).

Watari, N. and Y. Honma: Correlative light and electron microscopy of the principal islets in the pancreas of the yellow-tail fish. Abstr. 37th Anatomical Meeting of Kanto District. Acta anat. nippon. 44. 1968.

Winbladh, L.: Light microscopic and ultrastructural studies of the pancreatic islet tissue of the lamprey (Lampetra fluviatillis). Gen. comp. Endocrinol. 6: 534-543 (1966).

Winborn, W. B.: Light and electron microscopy of the islets of Langerhans of the saimiri monkey pancreas. Anat. Rec. 147: 65-94 (1963). 